PART I. DISEASES AND PROBLEMS DISTINGUISHED BY WHO AND FAO DZIAŁ I. CHOROBY I PROBLEMY WYRÓŻNIONE PRZEZ WHO I FAO

\title{
ASSESSMENT OF HEALTH BEHAVIORS OF PATIENTS WITH HEART FAILURE TREATED IN A CARDIOLOGY DEPARTMENT
}

\section{OCENA ZACHOWAŃ ZDROWOTNYCH PACJENTÓW Z NIEWYDOLNOŚCIĄ SERCA LECZONYCH W ODDZIALE KARDIOLOGII}

\author{
Elżbieta Szlenk-Czyczerska ${ }^{1(A, C, D, E, F)}$, Weronika Semla ${ }^{1(A, B, C, D, F)}$, Anna Maria Jenczura ${ }^{1(C, D, E, F)}$
}

\author{
${ }^{1}$ Department of Health Sciences, University of Opole, Poland
}

Authors' contribution Wkład autorów:

A. Study design/planning zaplanowanie badań B. Data collection/entry zebranie danych C. Data analysis/statistics dane - analiza i statystyki D. Data interpretation interpretacja danych E. Preparation of manuscript przygotowanie artykułu F. Literature analysis/search wyszukiwanie i analiza literatury G. Funds collection zebranie funduszy
Tables: 4

Figures: 0

References: 32

Submitted: 2021 Jan 6

Accepted: 2021 March 11

\section{Summary}

Background. Following pharmacological recommendations and leading a healthy lifestyle are imperative to improve the health and quality of life of patients with heart failure (HF). Material and methods. This cross-sectional, observational study examined 100 patients with $\mathrm{HF}$ who were treated in the cardiology department. The average age of the respondents was $70 \pm 14$ years (mean $\pm \mathrm{SD}$ ), and the majority were men (65\%). The Health Behavior Inventory Questionnaire and the authors' questionnaire were used.

Results. The respondents collectively reported an average level of health behaviors. There was a negative correlation between age and proper eating habits (rho=-0.248; $\mathrm{p}=0.013$ ) and a positive mental attitude (rho=-0.270; $p=0.007$ ). Higher or secondary education was associated with increased levels of health behaviors in all categories. Patients with a shorter duration of disease ( $<15$ years) were more likely to take pro-health measures in the categories of proper eating habits $(p=0.001)$ and positive mental attitude $(p=0.004)$. Patients with a higher level of knowledge about the disease demonstrated higher levels of health behaviors. Subjects who had a pacemaker/cardioverter implanted had lower positive mental attitudes $(\mathrm{p}=0.048)$.

Conclusions. It is important to encourage health behaviors in patients with HF. These actions should be aimed primarily at elderly people, with primary and vocational education, longer disease duration ( $>15$ years), lower knowledge of the disease, and/or an implanted cardioverter/pacemaker.

Keywords: patient, heart failure, health behaviors

\section{Streszczenie}

Wprowadzenie. Ogromne znaczenie dla poprawy stanu zdrowia oraz jakości życia chorych z niewydolnością serca (HF) ma zarówno przestrzeganie zaleceń farmakologicznych, jak również prowadzenie prozdrowotnego stylu życia.

Materiał i metody. Badanie to jest przekrojowym badaniem obserwacyjnym, w którym przebadano 100 pacjentów z HF leczonych w oddziale kardiologii. Średni wiek respondentów wynosił 70 \pm 14 lat (mean \pm SD), z przewagą mężczyzn (65\%). Wykorzystano Kwestionariusz Inwentarz Zachowań Zdrowotnych oraz ankietę autorska.

Wyniki. Analiza wykazała, że badani jako grupa prezentują przeciętny poziom zachowań zdrowotnych. Wiek negatywnie korelował z nasileniem prawidłowych nawyków żywieniowych $(\mathrm{r}=-0,248 ; \mathrm{p}=0,013)$ i pozytywnym nastawieniem psychicznym $(\mathrm{r}=-0,270 ; \mathrm{p}=0,007)$. Wyższe lub średnie wykształcenie wiązało się z nasileniem zachowań zdrowotnych we wszystkich kategoriach. Badani chorujący krócej (<15 lat) częściej podejmowali działania prozdrowotne $w$ kategorii prawidłowe nawyki żywieniowe $(\mathrm{p}=0,001)$ oraz wykazywali pozytywne nastawienie psychiczne $(p=0,004)$. Im wyższy był poziom wiedzy na temat choroby, tym wyższe było nasilenie zachowań zdrowotnych. Badani, którzy mieli wszczepiony stymulator/kardiowerter wykazywali niższe pozytywne nastawienie psychiczne $(p=0,048)$.

Wnioski. Istotnym jest stymulowanie zachowań zdrowotnych u pacjentów z HF. Działania te powinny być skierowane przede wszystkim do osób w wieku podeszłym, z wykształceniem podstawowym i zawodowym, dłuższym okresem trwania choroby ( $>15$ lat), niższym poziomem wiedzy na temat choroby oraz wszczepionym kardiowerterem/stymulatorem.

Słowa kluczowe: pacjent, niewydolność serca, zachowania zdrowotne 


\section{Introduction}

Heart failure (HF) is a chronic, life-threatening condition with significant morbidity and mortality and a serious burden for patients, their careers, and healthcare systems in Poland and worldwide [1,2]. In recent years, the number of patients with HF has increased. This is related to the increasingly effective treatment of cardiovascular diseases and demographic changes which reflect the aging of the population. In 2018, the number of HF patients in Poland amounted to 1.24 million - every thirtieth Pole is already sick. There is a constant increase in the incidence of patients in whom HF is the only cardiovascular disease [3-5]. The incidence of HF depends on age. The risk of the disease in people aged 55 years is $33 \%$ for men and $28 \%$ for women. In people over 70 years of age, the incidence of $\mathrm{HF}$ is as high as $10 \%$ of the population. In Poland, HF develops at earlier ages in comparison to other European countries. Moreover, Polish patients are characterized by a more severe course of the disease and lower independence. Among cardiovascular diseases, HF is the most common and costly reason for hospitalization of patients. The number of hospitalizations due to this disease in our country is the highest in Europe, amounting to 547 people per 100,000 inhabitants. HF is the most common direct cause of death in Poland, where the mortality rate due to HF is about 60,000 deaths per year [3,5-11].

Appropriate preventive measures and knowledge of management approaches to slow disease progression are necessary in order to maintain optimal health status of patients with HF for as long as possible [12]. Lifestyle has the greatest impact on our health [13]; therefore, a broadly-understood prophylaxis, including not only observing the pharmacological recommendations but also leading a healthy lifestyle, is of great importance for improving the health and quality of life of patients with HF. The pro-health behaviors that help to maintain optimal health status of patients with HF include healthy eating, physical activity, adequate sleep and rest, cardiac monitoring, vaccination, and mental health care. Changing lifestyles is not an easy task, as it requires discipline and a lasting change in habits $[6,14,15]$. Therefore, the aim of our research was to assess adherence to health behaviors in patients with HF treated in the cardiology department. We were also interested in whether select sociodemographic variables, patients' knowledge of the disease entity, and/or clinical parameters play a role in the adherence to health behaviors.

\section{Material and methods}

\section{Study design and participants}

This study was conducted from July to December 2019 in a group of 100 people hospitalized in the cardiology department of the University Clinical Hospital in Opole, Poland. Written consent was obtained from the Bioethics Committee of the PMWSZ in Opole (KB: 18/PI/2019). The criteria for inclusion in the study were as follows: 18 years of age or older and diagnosed with HF. The exclusion criteria were cognitive disorders and other serious mental illness and/or other difficulties preventing active participation in the study. Before the study, each participant was informed about the purpose, method, and anonymity of the study, as well as the option to withdraw from the study at each stage. Informed consent was obtained from all subjects involved in the study.

\section{Health Behavior Inventory}

This study is a cross-sectional observational study. The Health Behavior Inventory (HBI) of Zygfryd Juczyński [16] and a self-assessment questionnaire were used. The HBI consists of 24 statements describing various types of health-related behaviors. Respondents determine the frequency of health behaviors in four categories: proper eating habits, preventive behaviors, health practices, and positive mental attitudes. The proper eating habits category assesses of the type of food consumed (e.g. whole-grain bread, vegetables, and fruits). Preventive behaviors encompass adherence to health recommendations and obtaining information about health and illness. Health practices include physical activity and daily sleep and recreation habits. The positive mental attitude category assesses positive perceptions and the level of avoidance of excessive emotions, tensions and stress, and depressing situations. The questionnaire is designed for adults and intended for both healthy and sick individuals. Respondents utilize a five-point scale to indicate how often they perform health-related activities where 1 means 'almost never' and 5 means 'almost always'. The values for each category are summed in order to obtain an overall indicator of health behaviors with a range between 24 and 120. Higher scores reflect greater adherence to the declared health behaviors. In addition, mean scores were analyzed for four categories of health behaviors [16]. The reliability of the HBI was Cronbach's $\alpha=0.85$, which indicates good internal consistency [17]. 
The authors' questionnaire

The authors' questionnaire consisted of 18 questions. Questions 1 through 8 concerned sociodemographic data. The remaining questions asked about the duration of the disease, the occurrence of cardiovascular diseases in the family, knowledge about the disease, compliance with medical recommendations, use of stimulants (cigarettes and alcohol), physical and mental well-being, and whether the respondent has a cardioverter/ stimulator implanted. Respondents rated their mental and physical well-being as: 1: very bad; 2 : bad; 3: pretty good; 4: good; 5: great.

\section{Statistical analyses}

For the quantitative variables, the arithmetic mean, standard deviation, median, minimum, and maximum were calculated. For qualitative variables, frequency (percentage) was determined. For the analysis of quantitative variables presented by groups, the following parametric tests were used: Student's t-test or ANOVA and their non-parametric equivalents: Mann-Whitney U test or Kruskal-Wallis test. The selection of the tests was based on the distribution of variables, which was verified with the Shapiro-Wilk test. Correlations were tested using the Spearman correlation coefficient. Test values meeting the condition $\mathrm{p}<0.05$ were considered statistically significant. The calculations were performed in the statistical environment R ver.3.6.0, PSPP and MS Office 2019.

\section{Results}

\section{Sociodemographic data and clinical characteristics of respondents}

The average age of the respondents was $M=69.89$ years (SD=13.64), and the majority were men (65\%). Most respondents had vocational education (43\%), were married (52\%), and lived in the countryside (55\%). In general, respondents reported a good material situation (53\%). Analysis of the clinical parameters showed that $45 \%$ of respondents had a disease duration greater than 15 years and the majority had an implanted heart device (63\%). Moreover, $50 \%$ of respondents had a family history of cardiovascular disease (Table 1). Respondents complained most frequently about dyspnea (36\%) and cardiac edema (32\%). The majority followed recommendations for systematic medication intake (54\%) but did not follow recommendations for lifestyle (55\%) or dietary changes (57\%). Thirty-nine percent of respondents smoked cigarettes regularly. Frequent and regular alcohol consumption was declared by $17 \%$ and $9 \%$ of respondents, respectively. Overall, this was a group that declared physical and mental well-being $-57 \%$ of respondents.

Table 1. Sociodemographic and clinical data of patients

\begin{tabular}{|c|c|c|c|}
\hline \multicolumn{4}{|c|}{$\mathrm{n}=100$} \\
\hline \multicolumn{2}{|c|}{ Variable } & $\mathbf{n}$ & $\%$ \\
\hline \multirow{2}{*}{ Gender } & women & 35 & 35 \\
\hline & men & 65 & 65 \\
\hline \multirow{2}{*}{ Place of residence } & urban & 45 & 45 \\
\hline & rural & 55 & 55 \\
\hline \multirow{4}{*}{ Education } & primary & 15 & 15 \\
\hline & vocational & 43 & 43 \\
\hline & secondary & 25 & 25 \\
\hline & higher (BA/MA) & 17 & 17 \\
\hline \multirow{4}{*}{ Marital status } & single & 10 & 10 \\
\hline & married & 52 & 52 \\
\hline & divorced & 10 & 10 \\
\hline & widowed & 28 & 28 \\
\hline \multirow{3}{*}{ Material situation } & very good & 26 & 26 \\
\hline & good & 53 & 53 \\
\hline & bad & 21 & 21 \\
\hline \multirow{4}{*}{ Disease duration } & $>5$ years & 15 & 15 \\
\hline & $5-10$ years & 26 & 26 \\
\hline & $10-15$ years & 14 & 14 \\
\hline & $<15$ years & 45 & 45 \\
\hline
\end{tabular}




\begin{tabular}{|c|c|c|c|}
\hline \multirow{2}{*}{\begin{tabular}{c} 
Cardiovascular diseases in $\begin{array}{c}\text { the family } \\
\text { the }\end{array}$ \\
\cline { 2 - 4 }
\end{tabular}} & no & 50 & 50 \\
\cline { 2 - 4 } & don't know & 26 & 26 \\
\hline
\end{tabular}

Notes: BA - bachelor's degree; MA - master's degree.

\section{Health behaviors of patients with $H F$}

The mean health behavior score of respondents was 79.30 points (SD=17.15), with a possible range of 24-120 points. The minimum health behavior score among the respondents was 44 points, while the maximum was 111 points. When we analyzed each category of health behaviors, we found that positive mental attitude was rated highest $(M=3.37$ and $S D=0.84)$, followed by proper eating habits $(M=3.33$ and $S D=1.07)$, then preventive behaviors $(M=3.30$ and $S D=0.77)$, and health practices $(M=3.22$ and $S D=0.79)$. The distribution of variables reveals that the respondents as a group present an average level of health behavior (Table 2).

Table 2. HBI results $(n=100)$

\begin{tabular}{|c|c|c|c|c|c|}
\hline Variable & M & SD & Min & Max & Me \\
\hline Proper eating habits & 3.33 & 1.07 & 1.00 & 5.00 & 3.00 \\
\hline Preventive behavior & 3.30 & 0.77 & 1.50 & 4.67 & 3.33 \\
\hline Positive mental attitude & 3.37 & 0.84 & 1.67 & 4.83 & 3.33 \\
\hline Health practices & 3.22 & 0.79 & 1.50 & 4.83 & 3.17 \\
\hline Overall health behavior indicator & 79.30 & 17.15 & 44.00 & 111.00 & 78.00 \\
\hline
\end{tabular}

Notes: HBI - Health Behavior Index; M - mean; SD - standard deviation; Min - minimum; Max - maximum; Me - median.

\section{Health behaviors and selected sociodemographic variables}

There was no statistically significant effect of gender, marital status, material situation, or place of residence on the level of health behaviors in all categories. However, statistically significant correlations were found between age and proper eating habits ( $\mathrm{rho}=-0.248 ; \mathrm{p}=0.013$ ) and positive mental attitude (rho=-0.270; $\mathrm{p}=0.007)$. In addition, people with secondary or tertiary education reported higher scores in the following categories: proper eating habits $(\mathrm{p}<0.001)$, preventive behaviors $(\mathrm{p}=0.019)$, positive mental attitude $(\mathrm{p}<0.001)$, health practices $(\mathrm{p}=0.024)$, and general health behavior index $(\mathrm{p}<0.001)$ compared to patients with primary or vocational education.

\section{Health behaviors and disease duration}

Compared to those with a disease duration over 15 years, respondents with disease duration under 15 years were more likely to report taking pro-health measures in the category of proper eating habits $(p=0.001)$, had a higher level of positive mental attitude $(\mathrm{p}=0.004)$, and reported a higher overall indicator of health behaviors $(\mathrm{p}=0.017)$ (Table 3).

Table 3. HBI among patients with different duration of illness

\begin{tabular}{|c|c|c|c|c|c|c|c|c|c|}
\hline \multicolumn{2}{|c|}{ Variable } & $\mathbf{M}$ & SD & Min & Max & Me & t/U test & df & $\mathbf{p}$ \\
\hline \multicolumn{2}{|c|}{ Proper eating habits } & & & & & & 776.50 & & 0.001 \\
\hline \multirow{2}{*}{$\begin{array}{l}\text { Duration } \\
\text { of illness }\end{array}$} & $<15$ years & & & 1.00 & 5.00 & 4.00 & $\mathbf{U}$ & & \\
\hline & $>15$ years & & & 2.00 & 4.83 & 3.00 & & & \\
\hline \multicolumn{2}{|c|}{ Preventive behavior } & & & & & & 1.31 & 98 & 0.195 \\
\hline \multirow{2}{*}{$\begin{array}{l}\text { Duration } \\
\text { of illness }\end{array}$} & $<15$ years & 3.39 & 0.82 & & & & $\mathbf{t}$ & & \\
\hline & $>15$ years & 3.19 & 0.71 & & & & & & \\
\hline \multicolumn{2}{|c|}{ Positive mental attitude } & & & & & & 817.50 & & 0.004 \\
\hline \multirow{2}{*}{$\begin{array}{l}\text { Duration } \\
\text { of illness }\end{array}$} & $<15$ years & & & 2.00 & 4.83 & 3.67 & $\mathbf{U}$ & & \\
\hline & $>15$ years & & & 1.67 & 4.83 & 3.00 & & & \\
\hline
\end{tabular}




\begin{tabular}{|c|c|c|c|c|c|c|c|c|c|}
\hline \multicolumn{2}{|c|}{ Health practices } & & & & & & 0.40 & 98 & 0.689 \\
\hline \multirow{2}{*}{$\begin{array}{c}\text { Duration } \\
\text { of illness }\end{array}$} & $\mathbf{< 1 5}$ years & 3.25 & 0.82 & & & & $\mathbf{t}$ & & \\
\hline & $>15$ years & 3.18 & 0.76 & & & & & & \\
\hline $\begin{array}{c}\text { Overall health behavior } \\
\text { indicator }\end{array}$ & & & & & & 892.00 & & 0.017 \\
\hline \multirow{2}{*}{$\begin{array}{c}\text { Duration of } \\
\text { illness }\end{array}$} & $>\mathbf{1 5}$ years & & & 44.00 & 111.00 & 90.00 & $\mathbf{U}$ & & \\
\cline { 2 - 9 }
\end{tabular}

Notes: HBI - Health Behavior Index; t - Student's t-test statistics; U - Mann-Whitney U test statistics; df - degrees of freedom; p - statistical significance; M - mean; SD - standard deviation; Me - median; Min - minimum; Max - maximum.

Health behavior and level of knowledge about the disease, compliance with medical recommendations, and SELFassessment of physical and mental well-being

Subjects characterized by a higher level of knowledge about the disease reported higher levels of health behaviors in the following categories: proper eating habits $(p<0.001)$, preventive behaviors $(p<0.001)$, positive mental attitude $(\mathrm{p}<0.001)$, and health practices $(\mathrm{p}=0.012)$ in comparison with persons with lower levels of knowledge about the disease. Subjects applying recommendations for lifestyle changes and dietary recommendations as well as systematically taking medicines reported higher levels of health behaviors in the following categories: proper eating habits $(\mathrm{p}<0.001)$, preventive behaviors $(\mathrm{p}<0.001)$, positive mental attitude $(\mathrm{p}<0.001)$, and health practices $(\mathrm{p}<0.001)$. There was no statistically significant difference between health behaviors and assessment of physical and mental well-being.

\section{Health behavior and implantation of a pacemaker/cardioverter}

There was no statistically significant difference between subjects who had an implanted pacemaker compared to those without an implanted pacemaker in scores for proper eating habits $(\mathrm{p}=0.097)$, preventive behaviors $(\mathrm{p}=0.577)$, or health practices $(\mathrm{p}=0.310)$. Patients with HF who did not have a pacemaker/cardioverter implanted were characterized by greater health behaviors in the category of positive mental attitude $(p=0.048)$ in comparison with those who had such a device (Table 4).

Table 4. HBI among patients with or without an implanted pacemaker

\begin{tabular}{|c|c|c|c|c|c|c|c|c|c|}
\hline \multicolumn{2}{|c|}{ Variable } & $\mathbf{M}$ & SD & Min & Max & Me & t/U test & df & $\mathbf{p}$ \\
\hline \multicolumn{2}{|c|}{ Proper eating habits } & & & & & & 934.00 & & 0.097 \\
\hline \multirow{2}{*}{$\begin{array}{c}\text { Pacemaker/ } \\
\text { cardioverter } \\
\text { implanted }\end{array}$} & yes & & & 2.00 & 5.00 & 3.00 & $\mathbf{U}$ & & \\
\hline & no & & & 1.00 & 5.00 & 3.83 & & & \\
\hline \multicolumn{2}{|c|}{ Preventive behavior } & & & & & & -0.56 & 98 & 0.577 \\
\hline \multirow{2}{*}{$\begin{array}{c}\text { Pacemaker/ } \\
\text { cardioverter } \\
\text { implanted }\end{array}$} & yes & 3.33 & 0.70 & & & & $\mathbf{t}$ & & \\
\hline & no & 3.24 & 0.88 & & & & & & \\
\hline \multicolumn{2}{|c|}{ Positive mental attitude } & & & & & & 889.00 & & 0.048 \\
\hline \multirow{2}{*}{$\begin{array}{l}\text { Pacemaker/ } \\
\text { cardioverter } \\
\text { implanted }\end{array}$} & yes & & & 1.67 & 4.83 & 3.17 & $\mathbf{U}$ & & \\
\hline & no & & & 2.17 & 4.67 & 4.00 & & & \\
\hline \multicolumn{2}{|c|}{ Health practices } & & & & & & -1.02 & 98 & 0.310 \\
\hline \multirow{2}{*}{$\begin{array}{l}\text { Pacemaker/ } \\
\text { cardioverter } \\
\text { implanted }\end{array}$} & yes & 3.28 & 0.76 & & & & $\mathbf{t}$ & & \\
\hline & no & 3.11 & 0.83 & & & & & & \\
\hline \multicolumn{2}{|c|}{$\begin{array}{c}\text { Overall health behavior } \\
\text { indicator }\end{array}$} & & & & & & 1049.00 & & 0.407 \\
\hline \multirow{2}{*}{$\begin{array}{l}\text { Pacemaker/ } \\
\text { cardioverter } \\
\text { implanted }\end{array}$} & yes & & & 54.00 & 111.00 & 73.00 & $\mathbf{U}$ & & \\
\hline & no & & & 44.00 & 107.00 & 90.00 & & & \\
\hline
\end{tabular}

Notes: HBI - Health Behavior Index; t - Student's t-test statistics; U - Mann-Whitney U test statistics; df - degrees of freedom; $\mathrm{p}$ - statistical significance; M - mean; SD - standard deviation; Me - median; Min - minimum; Max - maximum. 


\section{Discussion}

This study examined the health behaviors of patients with HF treated in the cardiology department. The group of patients examined reported an average level of health behaviors. Positive mental attitude was rated the highest, followed by proper eating habits, then preventive behaviors and health practices. The results for total health behavior and specific categories of health behaviors are lower than those reported in men after myocardial infarction in Juczyński's analyses [16] and those of Szkup et al. [18].

Demographic and social determinants of health behaviors include age, gender, marital status, education, and material situation [14,19-21]. The results of this study show that gender, place of residence, marital status, and economic status did not significantly influence the levels of health behaviors reported in our cohort.

Our analysis showed that age significantly correlated with the level of health behaviors in the categories of proper eating habits and positive mental attitude. We observed a decrease in health behaviors in these categories with increasing age. In the category of positive mental attitude, similar results were obtained by Stanislawska, who showed that age strongly correlates with positive mental attitude. She also stated that the older the person, the greater the problem with complying with health behaviors [22]. According to Harton, older people are more likely to show a higher level of health behaviors in the category of proper eating habits [23]. The study by Muszalik confirms the above [21]. Our results in patients with HF indicate the need for further research in this area. Moreover, the elderly with HF should be included in an educational program on the beneficial effects of pro-health behaviors, with particular emphasis on proper eating habits. Psychological care is also important as the elderly patients show a lower level of positive mental attitude.

The analysis of our research shows that people with higher or secondary education were characterized by greater levels of health behaviors in all categories. The presented results are consistent with other studies. The study by Andruszkiewicz et al. shows that education influences the level of health behaviors [24], and ManieckaBryła et al. reported that the level of knowledge about cardiovascular risk factors increases with education [25]. Analysis of the Kurowska and Kudas studies shows a significant correlation between education and health behaviors. Patients with higher education presented greater levels of health behaviors in all categories [14]. Many publications emphasize that people with higher education are more likely to better adapt to the disease. It is believed that they are more willing to obtain new information; moreover, they are able to put the acquired knowledge into practice $[19,26]$. Our results indicate that education determines health behaviors, where patients with higher levels of education report higher levels of proper health behaviors.

Studies on the relationship between the duration of chronic disease and patients' health behaviors have shown that patients with longer disease duration demonstrate higher knowledge of proper nutrition and preventive measures [27,28]. Our study does not confirm this relationship. The analysis showed that people with shorter disease duration ( $<15$ years) were more likely to undertake health behaviors in the category of proper eating habits and also achieved a higher overall indicator of health behaviors compared to people with longer disease duration ( $>15$ years). In another study on health behaviors of patients with arteriosclerosis of the lower extremities, the time of disease had little influence on health behaviors; however, patients with longer duration of illness were more likely to undertake pro-health behaviors than those with shorter duration of illness [29]. Personality factors and an individual's personal resources influence the adoption of health behaviors [19]. Longer disease duration in patients with HF may be associated with overdependence on others, high levels of anxiety, feelings of isolation, and low self-esteem, as well as a lack of self-efficacy. These factors are not conducive to undertaking health behaviors. Moreover, in our study, we showed that a longer duration of the disease was associated with a lower positive mental attitude. Therefore, it can be concluded that people with a longer duration of the disease are more likely to feel the severity of the disease, are discouraged, and have a reduced mood.

Adherence to the doctor's prescriptions is crucial in patients with HF; however, the rate of non-adherence in the population of patients with $\mathrm{HF}$ is $50 \%$, which is a significant problem [30]. The results of our study confirm the above. The majority of patients did not follow lifestyle and dietary recommendations. Thirty-nine percent of respondents smoked cigarettes regularly, while many declared frequent and regular consumption of alcohol (17\% and 9\%, respectively).

According to Kaczyńska et al., implanting a pacemaker improved the emotional life of $38.9 \%$ of respondents. More than half of the respondents (69.5\%) estimated that their health condition was better than before the procedure [31]. In contrast, studies conducted by Rolka et al. showed that people over 76 years of age with an implanted pacemaker were more likely to experience emotional problems that hindered their daily lives [32]. In the present study, implantation of a pacemaker/cardioverter was associated with a lower positive mental attitude. It can be concluded that these individuals feel anxiety due to the conviction that they have exhausted their treatment options. 


\section{Limitations and future directions}

Limitations of this study include the relatively small sample size, the sample selection method, and the crosssectional design of the study, which limits our ability to generalize the results to the entire population of HF patients in Poland. Nevertheless, the results of this study are valuable and can be used in interventions to modify factors such as belief in self-care capacity, sense of control, and knowledge of self-care behaviors in HF patients. Future research should include more respondents.

\section{Conclusions}

It is important to stimulate health behavior in patients with HF with particular attention to elderly patients, those with primary and vocational education, and patients with longer disease duration ( $>15$ years), lower level of knowledge about the disease, and/or an implanted cardioverter/pacemaker.

\section{Disclosures and acknowledgements}

This research received no external funding. The authors declare no conflict of interest.

\section{References:}

1. Karasek D, Kubica A, Sinkiewicz W, Błażejewski ], Bujak R. [Heart failure epidemic - health and social problem of the aging society of Poland and Europe]. Folia Cardiologica Excerpta. 2008; 3(5): 242-248 (in Polish).

2. Zannad F. Rising incidence of heart failure demands action. Lancet. 2018; 391: 518-519. https://doi.org/10.1016/S0140-6736(17)32873-8_

3. Kałużna-Oleksy M., editor. [Heart failure in Poland. Reality, costs, suggestions for change] [Internet]. Warszawa: INNOWO; 2020 [cited 2021 Jan 6]. Available from: https://ptkardio.pl/resources/data/ pliki/42/2020_12_07_raport_niewydolnosci_serca_w_polsce.pdf?download=true (in Polish).

4. pulsmedycyny.pl [Internet]. Warszawa: Puls Medycyny; 2018 Jun 8. [WNEI report: heart failure as one of the most crucial medical needs in Poland] [cited 2021 Jan 2]. Available from: https://pulsmedycyny.pl/raportwei-niewydolnosc-serca-jedna-z-najwiekszych-potrzeb-medycznych-w-polsce-931598 (in Polish).

5. Łyszczarz B, Gierczyński J, Nojszewska E, Śliwczyński A, Zalewska H, Karczewicz E, et al., editors. [Assessment of heart failure costs in Poland in the context of state economy] [Internet]. Warszawa: Instytut Innowacyjna Gospodarka; 2017 [cited 2021 Jan 2]. Available from: https://ingos.pl/public/userfiles/pdf/Ocena_kosztow niewydolnosci_serca_w_Polsce_z_perspektywy_gospodarki_panstwa.pdf (in Polish).

6. European Society of Cardiology. [2016 ESC Guidelines for the diagnosis and treatment of acute and chronic heart failure]. Kardiologia Polska. 2016; 74(10): 1037-1147 (in Polish).

7. Lelonek M. [Heart failure - discharge management the crucial point in heart failure care]. Folia Cardiologica. 2018; 13(4): 371-377 (in Polish). https://doi.org/10.5603/FC.2018.0080

8. Sosnowska-Pasiarska B, Bartkowiak R, Wożakowska-Kapłon B, Opolski G, Ponikowski P, Poloński L, et al. Population of Polish patients participating in the Heart Failure Pilot Survey (ESC-HF Pilot). Kardiol Pol. 2013; 71(3): 234-40. https://doi.org/10.5603/KP.2013.0034

9. Nessler J, Zalewski J, Kozierkiewicz A, Gackowski A, Uchmanowicz I, Witkowski A, et al. [Project of comprehensive care program for patients with heart failure]. Kardiologia Inwazyjna. 2018; 13(6): 10-17 (in Polish).

10. Maniecka-Bryła I, Bryła M, Bryła P, Pikala M. The burden of premature mortality in Poland analysed with the use of standard expected years of life lost. BMC Public Health. 2015; 15: 101. https://doi.org/10.1186/s12889-015-1487-x

11. Nessler J, Gackowski A, Kozierkiewicz A, Ponikowski P. [Coordinated heart failure care in Poland: towards optimal organisation of the health care system]. Kardiologia Polska. 2018; 76(2): $479-487$ (in Polish). https://doi.org/10.5603/KP.2018.0050

12. Seongkum H, Moser DK, Lennieb TA, Riegel B, Chung ML. Gender differences in and factors related to selfcare behaviors: a cross-sectional, correlational study of patients with heart failure. International Journal of Nursing Studies. 2008; 45(12): 1807-1815. https://doi.org/10.1016/j.ijnurstu.2008.05.008

13. Woźniak M, Brukwicka I, Kopański Z, Kollár R, Kollárová M, Bajger B. [Individual and collective health]. Journal of Clinical Healthcare. 2015; 4: 1-3 (in Polish).

14. Kurowska K, Kudas A. [Influence of health behaviors on the quality of life of people with heart failure]. Folia Cardiologica Excerpta. 2013; 8(1): 1-8 (in Polish). 
15. Kłosińska M, Kasprzak JD. [Life with heart failure. Guide for the patients] [Internet]. Warszawa: Kreo Sp. z o.o.; 2013 [cited 2021 Jan 3]. Available from: https://www.servier.pl/poradnik/zycie-z-niewydolnosciaserca.pdf (in Polish).

16. Jurczyński Z. [Measurment tool in health promotion and psychology]. Warszawa: Pracownia Testów Psychologicznych Polskiego Towarzystwa Psychologicznego; 2012 (in Polish).

17. Cronbach LJ. Coefficient alpha and the internal structure of tests. Psychometrika. 1951; 16: $297-334$. https://doi.org/10.1007/BF02310555

18. Szkup M, Starczewska M, Skotnicka I. [Evaluation of health behaviours in patients qualified for cardiac surgery]. Family Medicine \& Primary Care Review. 2014; 16(2): 169-171 (in Polish).

19. Gruszczyńska M, Bąk-Sosnowska M, Plinta R. [Health-related behaviors as an essential part of human life activities. Attitude of Poles towards their own health]. Hygeia Public Health. 2015; 50(4): 558-565 (in Polish).

20. Schneider-Matyka D, Bieniasz E, Szkup M, Stanisławska M, Jurczak A. [Health behaviors of cardiovascular patients]. Forum Medycyny Rodzinnej. 2015; 9(2): 155-157 (in Polish).

21. Muszalik M, Zielińska-Więczkowska H, Kędziora-Kornatowska K, Kornatowski T. [Assessment of selected health behavior among elderly people in Juczyński's Inventory of Health Behavior regarding sociodemographic factors]. Probl Hig Epidemiol. 2013; 94(3): 509-513 (in Polish).

22. Stanisławska M, Rajzer M, Jurczak A, Augustyniuk K. [Adopting pro-health behaviors by cardiac patients]. Medical \& Health Sciences Review. 2015; 1(1): 19-26 (in Polish).

23. Harton A, Solik-Tomassi A, Narojek L, Myszkowska-Ryciak J, Gajewska D. [Adherence to the recommended daily food rations by men with coronary heart disease]. Probl Hig Epidemiol. 2011; 92: 557-560 (in Polish).

24. Andruszkiewicz A, Banaszkiewicz M. [Health promotion. Theoretical basis of health education]. Lublin: Wydawnictwo Czelej; 2008. p. 123-153 (in Polish).

25. Maniecka-Bryła I, Bigos I, Bryła M. [The awareness of CVD risk factors in the subpopulation of the postproductive age]. Medycyna Ogólna i Nauki o Zdrowiu. 2009; 15(2): 311-320 (in Polish).

26. Jankowska-Polańska B, Ilko A, Wleklik M. [Influence of the acceptance of the disease on quality of life of patients with hypertension]. Nadciśn Tętn. 2014; 18(3): 143-150 (in Polish).

27. Kurowska K, Ratajczyk M. [The impact of health behaviours on the quality of life of patients diagnosed with arterial hypertension]. Nadciśnienie Tętnicze. 2012; 16(6): 345-352 (in Polish).

28. Babiarczyk B, Małutowska-Dudek B. [Assessment of health behaviours in hypertensive in- and outpatients]. Pol Przeg Nauk Zdr. 2016; 1(46): 29-35 (in Polish).

29. Kurowska K. [Health behaviours versus the quality of life in patients with atherosclerosis of the lower extremities]. Pielęgniarstwo Chirurgiczne i Angiologiczne. 2013; 3: 107-114 (in Polish).

30. Andrews AM, Russell CL, Cheng AL. Medication adherence interventions for older adults with heart failure: a systematic review. Journal of Gerontological Nursing. 2017; 43(10): 37-45. https://doi.org/10.3928/00989134-20170523-01

31. Kaczyńska K, Czarnecka J, Kobos E, Sienkiewicz Z. [Quality of life of patients with peacemakers]. Pielęgniarstwo Polskie. 2017; 3(65): 469-472 (in Polish). https://doi.org/10.20883/pielpol.2017.63

32. Rolka H, Pilecka E, Kowalewska B, Krajewska-Kułak B, Jankowiak B, Klimaszewska K, et al. [Acceptance evaluation of disease and quality of life of patients with a pacemaker]. Piel Zdr Publ. 2012; 2(3): 183-192 (in Polish). 